\title{
Prolonged Survival Time of Allogeneic Skin Grafts in Host Pretreated with Somatic Cell Hybrids and Prednisolone
}

\author{
Tetsuro Nishinira, Hiroshi IshiI, Morio Kasai, and \\ Takehiko Tachibana* \\ The Second Department of Surgery, Tohoku University School \\ of Medicine, Sendai 980, and *Department of Immunology, \\ The Research Institute for Tuberculosis and Cancer, Tohoku \\ University, Sendai 980
}

Nishrhira, T., Ishil, H., Kasai, M. and Tachibana, T. Prolonged Survival Time of Allogeneic Skin Grafts in Host Pretreated with Somatic Cell Hybrids and Prednisolone. Tohoku J. exp. Med., 1979, 129 (1), 71-74- By applying somatic cell hybrids to transplantation immunity, the prolongation of survival time of mouse skin allografts was investigated. The hybrid cells (LJ) were made by cell fusion between $\mathrm{L}$ cells derived from $\mathrm{C} 3 \mathrm{H} / \mathrm{He}$ mouse and JLS-V9 cells derived from BALB/c mouse with UV-irradiated Sendai viruses. Skin grafts from female $(\mathrm{C} 3 \mathrm{H} / \mathrm{He} \cdot \mathrm{Jms} \times \mathrm{BALB} / \mathrm{c} \cdot \mathrm{Slc}) \mathrm{F}_{1}$ donors were transplanted to male $\mathrm{BALB} / \mathrm{c} \cdot$ Slc. The survival of the transplant in $\mathrm{BALB} / \mathrm{c}$ pretreated with the LJ cells and prednisolone showed a significant prolongation, compared with that in animals pretreated with only prednisolone or the LJ cells. The mean survival time and standard deviation of the grafts in mice injected with $1 \times 10^{5} \mathrm{LJ}$ cells i.v. 4 days before the grafting, and subsequently treated with prednisolone 50 $\mathrm{mg} / \mathrm{kg}$ i.p. 1 day before and at the time of the grafting were $17.3 \pm 2.2$ days. Controls were $9.2 \pm 0.4$ days. The mechanisms of prolongation of skin grafts were discussed in terms of cell-mediated immunity and humoral factors. Somatic cell hybrids are useful, not only for inducing immunological enhancement, but also for studying the function of major histocompatibility antigens in cellular immunity and can be applied to clinical organ transplantation. - somatic cell hybrids; prolongation of skin grafts; immunological enhancement; selective hyporesponsiveness

Somatic cell hybridization has recently been applied to the induction of tumor immunity (Watkins and Chen 1969; Tachibana et al. 1974), in addition to its usefulness for the analyses of the location of gene loci on human chromosomes. It has been generally demonstrated that somatic cell hybrids express codominantly the surface antigens which are introduced by both parental cells (Spencer et al. 1964;

Received for publication, September 16, 1978.

This work was supported in part by the Grant for Cancer Rsearch in 1977 (Grant No. 201032) from the Ministry of Education, Science and Culture, and the Grant for Cancer Research in 1977 and 1978 (Grant No. 52-11) from the Ministry of Welfare, Japan.

A part of the content of this paper was reported at VII International Congress of the

Transplantation Society held in Rome on September 8, 1978. 
Silagi 1967). Also, it has been reported that the growth of some somatic cell hybrids of tumor cells with normal cells is suppressed even in normal syngeneic host and that they concomitantly induce the resistance of the host to the challenge of parental tumor cells (Tachibana et al. 1974; Liang and Cohen 1976). It means that somatic cell hybrids can evoke an efficient $\mathrm{T}$ cell reactivity in the normal host.

Thus, the clonal expansion of immune cells specifically reactive to allogeneic antigens can be induced by the inoculation of somatic cell hybrids. This clonal expansion may be reduced by the subsequent administration of immunosuppressant. But, the antibody produced may remain after immunosuppression and would be expected to work on as an enhancing antibody. It is possible, therefore, that the inoculation of somatic cell hybrids followed by immunosuppressant would bring about beneficial effects on the survival of grafting tissue.

We have attempted to apply somatic cell hybridization to the research on transplantation immunology. This is the first report concerning the survival effect on skin grafting based on the combination of inoculation of somatic cell hybrids with subsequent administration of immunosuppressive drug.

\section{Materials and Methods}

8-azaguanine resistant $\mathrm{L}$ cells derived from $\mathrm{C} 3 \mathrm{H} / \mathrm{He}$ mouse $\left(\mathrm{H} \cdot 2^{\mathrm{k}}\right)$ were fused with 5 -bromodeoxyuridine resistant JLS-V9 cells derived from BALB/C mouse (H-2d) by using UV-irradiated Sendai viruses (Murayama-Okabayashi et al. 1971). The hybrid cells (LJ) were selected in HAT medium. The LJ hybrids were maintained in Eagle's MEM medium supplemented with $10 \%$ calf sarum and expressed both parental $\mathrm{H}-2$ haplotypes $\left(\mathbf{H}-2^{\mathrm{d} / \mathrm{k}}\right)$.

The recipients were injected with $1 \times 10^{5} \mathrm{LJ}$ cells i.v. 4 days before the grafting, and treated with prednisolone $50 \mathrm{mg} / \mathrm{kg}$ i.p. 1 day before and at the time of the grafting. Full thickness skin grafts from female $(\mathrm{C} 3 \mathrm{H} / \mathrm{He} \cdot \mathrm{Jms} \times \mathrm{BALB} / \mathrm{c} \cdot \mathrm{Slc}) \mathrm{F}_{1}$ donors were transplanted to the back of male BALB/c. Slc mice. Ten to 20 mice were used as an experimental or a control group.

One way mixed lymphocyte reaction (MLR) was performed with peripheral blood lymphocytes (PBL) obtained from axillary arteries (Nishihira and Fujii 1972). Stimulating cells of $F_{1}$ hybrid PBL were irradiated with 1,000 rads electron beam and those of LJ cells with 8,000 rads.

\section{Results}

The survival of the transplant in $\mathrm{BALB} / \mathrm{c}$ mice treated with prednisolone and the LJ cells showed a significant prolongation, compared with that in animals treated with only prednisolone or the LJ cells.

The mean survival time and the standard deviation of the grafts are shown in Table 1. The combination of $\mathrm{F}_{1}$ hybrid spleen cells or bone marrow cells carrying the same $\mathrm{H}-2^{d / \mathrm{k}}$ haplotypes and prednisolone did not induce any significant prolongation of the grafts.

One way MLR between FI mice and the recipients with prolonged skin graft was lower than the MLR between $\mathrm{F}_{1}$ mice and normal BALB/c mice. The sera of the recipients with prolonged skin graft inhibited the MLR between $F_{1}$ mice and normal BALB/c mice, suggesting the presence of blocking factors. The LJ cells 
TABLE 1. Survial times of skin allografts $\left((\mathrm{C} 3 \mathrm{H} / \mathrm{He} \times \mathrm{BALB} / \mathrm{c}) \mathrm{F}_{1} \rightarrow \mathrm{BALB} / \mathrm{c}\right)$

\begin{tabular}{cccc}
\hline $\begin{array}{c}\text { Pretreatment of } \\
\text { recipients with }\end{array}$ & $\begin{array}{c}\text { Number } \\
\text { of mice }\end{array}$ & $\begin{array}{c}\text { Survival time of the grafts } \\
\text { (mean } \pm \text { s.D.) }\end{array}$ & $\begin{array}{c}\text { Difference from } \\
\text { control }\end{array}$ \\
\hline $\begin{array}{l}\text { LJ hybrids, } 1 \times 10^{6} \text { cells } \\
\text { i.v. }(-4 \text { day) }\end{array}$ & 11 & $9.3 \pm 1.0$ & $p<0.1$ \\
$\begin{array}{l}\text { Prednisolone, } 1 \mathrm{mg} / 20 \mathrm{~g} \\
\text { i.p. }(-1 \text { and } 0 \text { days) }\end{array}$ & 10 & $9.9 \pm 1.3$ & $p<0.1$ \\
$\begin{array}{l}\text { LJ hybrids, } 1 \times 10^{8} \text { cells } \\
\text { i.v. (-4 day) and } \\
\text { prednisolone, } 1 \mathrm{mg} / 20 \mathrm{~g}\end{array}$ & 10 & $17.3 \pm 2.2$ & $p<0.01$ \\
i.p. $(-1$ and 0 days) & & & \\
\hline
\end{tabular}

irradiated with 8,000 rads stimulated more strongly BALB/c lymphocytes in MLR than $\mathrm{F}_{1}$ hybrid spleen cells or bone marrow cells as stimulator cells.

\section{Discussion}

Transplantation immunology has clarified that the specificity of the antigens involved in graft rejection is under genetic control. Of many gene loci controlling these antigens, one complex locus termed the major histocompatibility complex (MHC) controls the strong transplantation antigens such as $\mathrm{H}-2$ antigens in mouse and HLA antigens in man which provoke intense allograft reactions. Therefore, it is reasonable that allograft rejection would be prevented by matching donor and recipient at the MHC locus. But, it is practically difficult to obtain an identical matching of the MHC. Thus, general immunosuppression and immunological enhancement are considered as other possibilities for the prevention of graft rejection. However, the induction of immunological enhancement of the graft has not even now been successful, unlike such an effect on survival of tumor allografts. Recently, another possibility has been suggested that autoantiidiotypic immunity after antigen-specific blast immunization could be useful for survival of grafts by the induction of specific reduction in $\mathrm{T}$ cell reactivity against the relevant alloantigens (Aguet et al. 1978).

Our preliminary results described here suggest the possibilities of the induction of enhancement phenomenon as well as a presumably selective decrease of $\mathrm{T}$ cells reactive to the relevant alloantigens in addition to general immunosuppression by the pretreatment of the recipients with the combination of somatic cell hybrid and immunosuppressant. The problems concerning doses of immunization cells, times of injection and programming of the combination of the hybrid cells with immunosuppressant still remain to be solved. Further investigations of the mechanisms on prolonged survival of graft are in progress.

\section{References}

1) Aguet, M., Andersson, L.C., Andersson, R., Weight, E., Binz, H. \& Wigzell, H. (1978) Induction of specific immune unresponsiveness with purified mixed leukocyte cultureactivated $T$ lymphoblasts as autoimmunogen. II. An analysis of the effects measured at the cellular and serological levels. J. exp. Med., 147, 50-62. 
2) Liang, W. \& Cohen, E.P. (1976) Resistance to murine leukemia in mice rejecting syngeneic somatic hybrid cells. $J$. Immunol., 116, 623-636.

3) Murayama-Okabayashi, F., Okada, Y. \& Tachibana, T. (1971) A series of hybrid cells containing different ratios of parental chromosomes formed by two steps of artificial fusion. Proc. nat. Acad. Sci., 68, 38-42.

4) Nishihira, T. \& Fujii, G. (1972) Mixed lymphocyte-platelet, lymphocyte-kidney cell, and lymphocyte-liver cell reactions in rats. Tohoku J. exp. Med., 108, 1-7.

5) Silagi, S. (1967) Hybridization of a malignant melanoma cell line with $\mathrm{L}$ cells in vitro. Cancer Res., 27, 1953-1960.

6) Spencer, R.A., Hauschka, T.S., Amos, D.B. \& Ephrussi, B. (1964) Codominance of isoantigens in somatic hybrids of murine cells grown in vitro. J. nat. Cancer Inst., 33, 893-903.

7) Tachibana, T., Dei, T. \& Nori, C (1974) Hybrids between malignant and normal cells. Gann Monograph on Cancer Rsearch, 16, 183-193.

8) Watkins, J.F. \& Chen, L. (1969) Immunization of mice against Ehrlich ascites tumor using a hamster/Ehrlich ascites tumor hybrid cell line. Nature, 223, 1018-1022. 